\section{INHIBITION OF CHLORAMPHENICOL O-ACETYLTRANSFERASE OF ESCHERICHIA COLI BY BASIC TRIPHENYLMETHANE DYES}

Sir :

Recently, the inactivation of various antibiotics such as chloramphenicol, streptomycin and kanamycin has been demonstrated in the cell-free extracts of multiple drug-resistant Escherichia coli carrying $\mathrm{R}$ factors. ${ }^{1,2,3,4)}$ Chloramphenicol has been shown to be acetylated to form the 3-O-acetyl and 1,3-O,Odiacetyl derivatives of chloramphenicol. ${ }^{5,6}$ ) During the search for an effective drug to eliminate $\mathrm{R}$-factors from resistant strains of $E$. coli, we found that a combination of basic triphenylmethane dyes and chloramphenicol had a synergistic inhibitory effect on the growth of the resistant strain of $E$. coli. Enzymatic experiments revealed that various basic triphenylmethane dyes such as crystal violet, ethyl violet and methyl violet were strong inhibitors of the chloramphenicol O-acetyltransferase of E. coli.

Resistant and sensitive strains of $E$. coli

Fig. 1. Effects of chloramphenicol and basic triphenylmethane dyes on the growth of $\mathrm{R}$ factor-resistant $E$. coli $\mathrm{C}-25$.

The bacterium was grown aerobically in nutrient broth. The following additions were made : No addition (No), $2 \mu \mathrm{g} / \mathrm{ml}$ crystal violet (CV), $2 \mu \mathrm{g} / \mathrm{ml}$ ethyl violet (EV), $60 \mu \mathrm{g} / \mathrm{m} 1$ chloramphenicol (CP), $60 \mu \mathrm{g} / \mathrm{ml}$ chloramphenicol and $2 \mu \mathrm{g} / \mathrm{ml}$ crystal violet $(\mathrm{CP}, \mathrm{CV}$ ), and 60 $\mu \mathrm{g} / \mathrm{m} 1 \mathrm{ch} 1$ oramphenicol and $2 \mu \mathrm{g} / \mathrm{m} 1$ ethy1 violet (CP,EV).

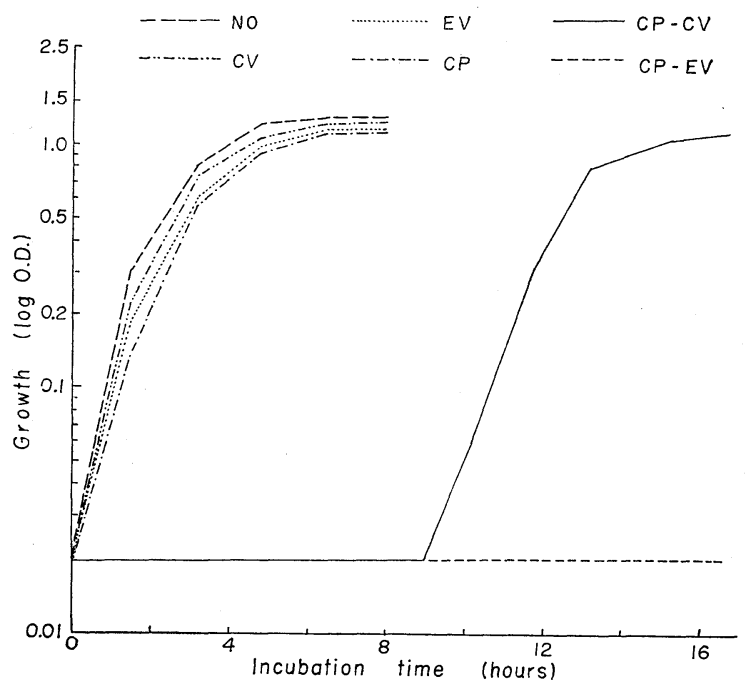

C-25 were kindly given by Dr. T. Yokota, Tokyo University. The resistant strain was resistant to chloramphenicol, streptomycin, tetracycline and sulfonamide. A bacterial suspension $(0.05 \mathrm{ml})$ in stationary growth phase was inoculated into $8 \mathrm{ml}$ of nutrient broth containing $0.04 \mathrm{M}$ of phosphate buffer and various concentrations of chloramphenicol with or without basic triphenylmethane dyes, and incubated at $36^{\circ} \mathrm{C}$ with shaking. Bacterial growth was followed by measuring the optical density at $660 \mathrm{~m} \mu$ with a Hitachi FPW 4 colorimeter. As shown in Fig. 1, growth of the resistant strain of $E$. coli C-25 was not significantly inhibited in the presence of chloramphenicol at the concentrations from 10 to $100 \mu \mathrm{g} / \mathrm{ml}$ or basic triphenylmethane dye from 2 to $5 \mu \mathrm{g} / \mathrm{ml}$. However, the growth of this strain was severely inhibited when both chloramphenicol and a basic triphenylmethane dye were added together. Among the basic triphenylmethane dyes tested, ethyl violet had much higher activity than crystal violet or methyl violet. The synergistic effect of chloramphenicol and basic triphenylmethane dyes was not observed with the sensitive strain.

No synergistic effect was found when streptomycin or tetracycline was used instead of chloramphenicol, even in the case of the resistant strain. This result suggests that the synergistic effect was specifically between basic triphenylmethane dyes and chloramphenicol. From the growth experiments described above, inhibition of chloramphenicol O-acetyltransferase by basic triphenylmethane dyes could be expected. Therefore, we examined the effects of these basic dyes on the $\mathrm{O}$-acetyltransferase reaction utilizing an in vitro system. Crude extracts were obtained from the early stationary phase cells of the resistant strain of $E$. coli $\mathrm{C}-25$ by the following method. An overnight culture was diluted 20-fold with fresh nutrient broth, and the cells were grown at $30^{\circ} \mathrm{C}$ with shaking for 3 hours. After harvesting and washing, the cells (about $3.5 \mathrm{~g}$ of wet weight) were suspended in $20 \mathrm{ml}$ of $0.02 \mathrm{M}$ tris$\mathrm{HCl}$ buffer ( $\mathrm{pH} 7.8$ ) containing $0.06 \mathrm{M}$ of $\mathrm{KCl}, 0.01 \mathrm{M}$ of magnesium acetate and 
$0.006 \mathrm{M}$ of 2-mercaptoethanol. The cell suspension was then sonicated at $10 \mathrm{Kc}$ for 20 seconds using a Kubota sonic oscillator. The supernatant obtained after centrifugation at $24,000 \times g$ for 30 minutes was dialyzed for 24 hours at $0^{\circ} \mathrm{C}$ against 20 volumes of the same buffer with 3 changes, and the dialyzed supernatant was again centrifuged at $105,000 \times g$ for 90 minutes. The supernatant thus obtained was used as the enzyme preparation. The supernatant was incubated with chloramphenicol and other compounds as shown in Fig. 2. Reaction was stopped by heating at $95^{\circ} \mathrm{C}$ for 5 minutes, and the reaction mixture was extracted twice with $50 \mu l$ of ethyl acetate. The ethyl acetate extract was spotted on Toyo Filter paper No. $51 \mathrm{~A}$ and developed with benzenemethanol-water (98:2:2, upper phase). A scan of the strip in an Aloka thin-layer chromatogram scanner is shown in Fig. 2. The left arrow in Fig. 2 represents residual chloramphenicol, while the right arrow represents the biologically inactive 3-Oacetyl derivative of chloramphenicol. 1,3$\mathrm{O}, \mathrm{O}$-Diacetyl derivative appears near the solvent front on prolonged incubation. As shown in Fig. 2, the formation of 3-Oacetyl chloramphenicol was almost completely inhibited in the presence of $9 \mu \mathrm{g} / \mathrm{ml}$ crystal violet. From these results, we conclude that the synergistic inhibitory effect of chloramphenicol and triphenylmethane dye on the growth of the resistant strain of $E$. coli was mainly due to the inhibition of chloramphenicol O-acetyltransferase by the triphenylmethane dye. Further studies on the mechanism of the inhibition of chloramphenicol O-acetyltransferase by triphenylmethane dyes are now in progress.

\section{Hiroshi Tanaka \\ Osamu Kudō \\ Kiyoshi Satō \\ KaZUO IZAKI \\ Hajime Takahashi}

Department of Agricultural Chemistry,

Faculty of Agriculture,

Tohoku University,

Sendai, Japan

(Received February 8, 1971)
Fig. 2. Inhibition of chloramphenicol O-acetyltransferase by crystal violet.

The reaction mixture A contains $2 \mu \mathrm{mol}$ Tris $-\mathrm{HCl}$ buffer ( $\mathrm{pH} 7.8$ ), $2.4 \times 10^{-2} \mu \mathrm{mol}$ of acety1-CoA, $1.7 \times$ $10^{-2} \mu \mathrm{mol}\left(1.8 \times 10^{4} \mathrm{cpm}\right),{ }^{14} \mathrm{C}$-chloramphenicol $(8.5 \mathrm{mC} /$ $\mathrm{mM}$ ), and crude extract $(0.4 \mu \mathrm{g}$ of protein) in a total volume of $20 \mu \mathrm{l}$. The reaction mixtue B contained crystal violet $(9 \mu \mathrm{g} / \mathrm{ml})$ in addition to reaction mixture A. Both mixtures were incubated at $37^{\circ} \mathrm{C}$ for 10 minutes.
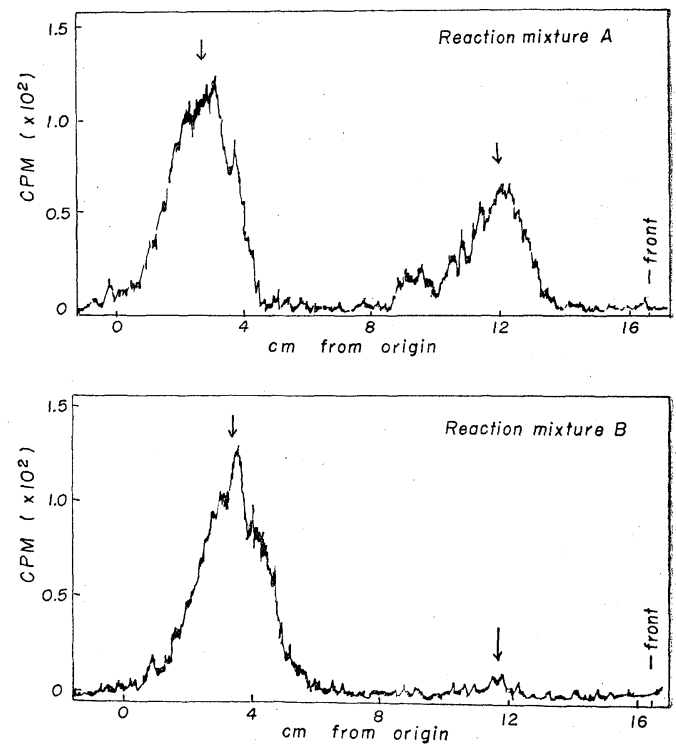

References

1) Окамото, S. \& Y. Suzuki: Chloramphenicol-, dihydrostreptomycin-, and kanamycininactivating enzymes from multiple drugresistant Escherichia coli carrying episome 'R'. Nature 208 : 1301 1303, 1965

2) Umezawa, H.; S. Takasawa, M. OKanishi \& R. Utahara: Adenylylstreptomycin, a product of streptomycin inactivated by $E$. coli carrying $\mathrm{R}$ factor. J. Antibiotics 21 : $81 \sim 82, \quad 1968$

3) Umezawa, H.; M. Okanishi, R. Utahara, K. MAEDA \& S. Kondo: Isolation and structure of kanamycin inactivated by a cell free system of kanamycin-resistant $E$. coli. J. Antibiotics $20: 136 \sim 141,1967$

4) Umezawa, H.; M. Okanishi, S. Kondo, K. Hamana, R. Utahara, K. Maeda \& S. MrtsuHASHI: Phosphorylative inactivation of aminoglycosidic antibiotics by $E$. coli carrying $\mathrm{R}$ factor. Science $157: 1559 \sim 1561,1967$

5) SHAw, W. V.: The enzymatic acetylation of chloramphenicol by extracts of $\mathrm{R}$ factorresistant E. coli. J. Biol. Chem. 242:687〜 693, 1967

6) Suzuki, Y. \& S. Oкамото: The ezymatic acetylation of chloramphenicol by multiple drug-resistant $E$. coli carrying $\mathrm{R}$ factor. J. Biol. Chem. $242: 4722 \sim 4730,1967$ 